\title{
Biodegradation of crude petroleum by bacterial consortia from oil-contaminated soils in Ota, Ogun State, South-Western, Nigeria
}

\author{
Yemisi Dorcas Obafemi ${ }^{\mathrm{a}}$, Olugbenga Samson Taiwo ${ }^{\mathrm{a}}$, Oladele Julius Omodara ${ }^{\mathrm{b}}$, \\ Olatunde Samuel Dahunsi ${ }^{\mathrm{c}}$, Solomon Oranusi ${ }^{\mathrm{a}, *}$ \\ a Department of Biological Sciences, Covenant University, Ota, Nigeria \\ ${ }^{\mathrm{b}}$ Department of Chemical Engineering, Covenant University, Ota, Nigeria

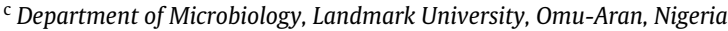

\section{H I G H L I G H T S}

- Biodegradation of crude and processed oils using indigenous isolates was evaluated.

- Four major bacteria strains were able to utilize petroleum as energy source.

- Both aliphatic and aromatic components of crude petroleum were reduced differently.

- There is evidence that petroleum degradation capabilities could be plasmid encoded.

\section{A R T I C L E I N F O}

\section{Article history:}

Received 24 November 2017

Received in revised form 16 September 2018

Accepted 22 September 2018

Available online 4 October 2018

\section{Keywords:}

Biodegradation

Bioremediation

Aliphatics

Aromatics

Gas chromatography

\begin{abstract}
A B S T R A C T
Pollution from petroleum products is of public health concern because of its attendant health and environmental impacts. Biodegradation of Bonny light crude petroleum and other selected hydrocarbons by bacteria isolated from soils of three different mechanic workshops in Ota, Ogun State were studied. Species of bacteria were isolated by the enrichment of the soil samples in minimal salt medium supplemented with $1 \%(\mathrm{v} / \mathrm{v})$ crude petroleum as the sole carbon and energy source. The petroleum utilizing bacteria belonging to the genera Bacillus sp. SB4, Pseudomonas sp. SC8, Serratia sp. SC11, and Acinetobacter sp. SC12 were screened and subjected for oil degradation using turbidity and total viable count, reduction in $\mathrm{pH}$ and residual oil concentration as indices. Gas Chromatographic (GC) analysis was used to analyze the component and percentage of the petroleum utilized. Plasmid curing and profiling were done to determine whether the ability to utilize carbon is plasmid or chromosomally encoded. Results revealed that four bacteria strains were able to utilize petroleum as energy source. The GC fingerprints showed that both the aliphatic and aromatic components of crude petroleum were reduced to varying degree but the nonadecane C19 could not be reduced. Strain SC11 could not reduce anthracene, pyrene, benzo(a)pyrene and chrysene components. Strain SB4 depleted 24 to 57\% aliphatics and 20 to $42 \%$ aromatics and strain SC8 depleted 38 to $67 \%$ aliphatics and 30 to $79 \%$ aromatics while strain SC11 depleted 12 to $46 \%$ aliphatics and 13 to $29 \%$ aromatics. All organisms harbored plasmid which could suggest that petroleum degradation capabilities could be plasmid encoded. This indicates that the petroleum utilizing bacteria are could be used bioremediation of the petroleum polluted environment.
\end{abstract}

(C) 2018 Elsevier B.V. All rights reserved.

\footnotetext{
* Corresponding author.

E-mail address: solomon.oranusi@covenantuniversity.edu.ng (S. Oranusi).
} 


\section{Introduction}

Crude oil composes of complex Polycyclic aromatic hydrocarbons (PAHs) and several other organic pollutants with great potentials too cause serious hazards in the spate of environmental catastrophes like uncontrolled drilling, oil spills, soil and water pollution etc. (Xu and Lu, 2010; Ting et al., 2011; Roy et al., 2014). The most widely used primary source of energy is the hydrocarbons; this is because they are source of large amounts of energy. Hydrocarbons molecules that make up crude petroleum and other oil components are highly toxic to microorganisms, plants, animals and humans (Haritash and Kaushik, 2009; Nie et al., 2012). Oil pollution results from routine normal operations of crude oil exploration, exploitation, refining, and transportation (Wu et al., 2010; Nwankwegu and Onwosi, 2017). Whenever crude oil is released into the environment; it causes enormous pollution which can be deliberate or by accidental. The issues often cause a lot of problems to both the living and non-living components of the environments, more so that some hydrocarbon components have been identified to belong to a family of substances that can cause cancer and other central nervous system disorders. There are other ways through which petroleum also penetrates into the environments; these could be through waste disposal, accidental spills, leakage tankers, oil bunkering, vandalization of oil pipes and losses during storage (Chen et al., 2015). The fact that petroleum product dominates the Nigerian's economy also creates a lot of conditions for exposure of large amounts of these toxins into environments (Nishant et al., 2016). Bonny light Crude petroleum is mainly composed of different components of hydrocarbon molecules, which are mainly alkanes from C1 to C30 aliphatics, C6-C8 aromatics, cyclohexanes, and other compounds containing nitrogen, oxygen and sulphur (Nishant et al., 2016). Major components in the petroleum pollutants are degradable, and they will become utilized from the environment as microorganisms use them for source of carbon and energy (Nwinyi and Olawore, 2017).

Though physicochemical treatment of oil contaminants is popular, use of bioremediation is a better alternative due to its numerous benefits in terms of efficiency and economics (Janbandhu and Fulekar, 2011; Suja et al., 2014). Biodegradation of crude petroleum by natural strains of bacteria represents one of the main processes of eliminating environmental pollution from the environment (Mona et al., 2016). Bacteria from genera Arthrobacter, Bacillus Pseudomonas, Acinetobacter, Flavobacterium, Rhodococcus Mycobacterium isolated from soil and other environmental samples are well-known PAHdegraders (Suja et al., 2014). All these microorganisms have been noted to have the ability to utilize and use petroleum resources as source of energy as they successfully mineralized different PAHs. Several bacteria species and strains have been identified to be capable of utilizing PAHs as a carbon source (Ting et al., 2011), it has been proposed that better results may be obtained by using mixed bacterial culture or bacterial-fungal consortium (Silva et al., 2009a,b; Xu and Lu, 2010). In real life situation, use of pure strain in biodegradation of contaminated soils is not representative of the real characteristics of environmental microorganisms. This is more so because the success of the bioremediation process is a function of the cooperative metabolic activities of microbial consortia (Hesnawi and Mogadami, 2013; Roy et al., 2014; Yenn et al., 2014). One major advantage of using microbial consortia is the possession of multiple metabolic capabilities which enhances increased efficiency of the bioremediation process (Zhang et al., 2010; Adekunle and Adeniyi, 2015)

In the light of the above, the isolation and proper characterization of bacteria surviving in oil-contaminated soils and their succession pattern is a gateway to achieving success in any bioremediation process (Zhang et al., 2010). The best method of decontamination of the environment polluted with petroleum components is an application of methods based mainly on metabolic activity of microorganisms (Groudev et al., 2014). This ability to actively utilize particular components of petroleum oil is expressed by many microorganisms which could be plasmid encoded. The biodegrading ability of any microorganism is a function of its genetic makeup while the various arrays of chemical reactions involved in the microbial metabolic pathways are enzyme mediated. Several previous researches focusing on the characterization of bacterial enzymes and the various pathways responsible for the degradation of hydrocarbon has been carried out. Prominent examples are the characterization of alkane mono-oxygenase (alkB) and cytochrome P450 families which are known to be actively involved in petroleum degradation pathways (van Beilen et al., 2006; van Beilen and Funhoff, 2007). Also, the genome sequences of several hydrocarbon-degrading bacteria have been documented in previous studies. Such bacteria include Alcanivorax borkumensis SK2, Geobacillus thermodenitrificans NG80-2, Desulfatibacillum alkenivorans AK-01, Polymorphum gilvum SL003B26A1T and Pseudomonas aeruginosa N002; Callaghan et al., 2012; Nie et al., 2012). Numerous potential genes and pathways in relation to hydrocarbon degradation have also been obtained from complete genome sequencing. This research therefore was aimed at (i) isolation and identification of petroleum utilizing or degrading bacteria strains from oil contaminated soil using basic microbiological techniques, (ii) screening of the isolated bacterial strains for degradation of petroleum and other hydrocarbon substrates, (iii) determination of the components of the crude petroleum that could be utilized or degraded by the bacterial isolate and evaluation of their percentage degradation and (iv) determination of the role of plasmid in the biodegradation process. This is necessary as a means of cleaning up the over three decades old constantly polluted soils and which have not been given any research attention prior to this study.

\section{Materials and methods}

\subsection{Collection of soil samples}

Ten soil samples each were randomly collected in duplicates from three locations (A, B and C) heavily contaminated with petroleum products as a result of constant disposal of waste oils for over three decades. Collection of soil samples were 
aseptically carried out from a layer of 0 to $3 \mathrm{~cm}$ deep and into sterilized bags. From each location of collection, bulk samples were prepared from minimum of three samples and used as the representative from the location. Each soil was later ground and made to pass through of $2 \mathrm{~mm}$ mesh size in order to get rid of large and unwanted particles. They were then taken to the Microbiology laboratory of Covenant University Ota, Ogun State within an hour of collection for analysis. They were initially kept at $4{ }^{\circ} \mathrm{C}$ till further physicochemical and microbial assays.

\subsection{Source of hydrocarbons}

Bonny light crude oil was obtained from Nigerian National Petroleum Corporation (NNPC). Other petroleum products used; Engine oil and Kerosene was obtained from a registered filling station for comparative purposes. They were all collected in sterile universal bottles and stored at room temperature for till further use.

\subsection{Soil physicochemical analysis}

The physical examination of the soil samples was observed. Two gram of the soil samples each were crushed using laboratory crucible and added into three test tubes. The tubes were filled with distilled water and mixed thoroughly. The $\mathrm{pH}$ and temperature of the soil were measured with the use of a multi task bench meter (ADWA BENCH METER MODEL NO AD1030 USA). Soil pH determination was carried using a 1:2 soil to water ratio. Soil total organic carbon (TOC) was determined by the Walkley-Black method while soil total nitrogen (TN) was evaluated using the Kjeldahl digestion apparatus. For phosphorus (P), determination was done by phospho molybdic acid while potassium (K) was determined by Flame photometry according to the protocols of Jackson (1973) and Roy et al. (2014) respectively. The concentrations of major anions were determined using the Ultraviolet spectrophotometer screening method (UV spectrophotometer, DR 2800, $\mathrm{HACH}$, Washington, USA) following the protocols of the American Public Health Association (APHA, 2012) and the method of Dahunsi et al. (2014). Analyses of blank, standard, and pre-analyzed samples were carried out after every 10 samples in order for the purpose of reliability and reproducibility. Determination of moisture content was done by first weighing empty petri dish and reweighing after addition of known weight of the soil samples. Drying of the soil was then carried out using the oven (Fisher Isothem ${ }^{\circledR}$ Oven Model) at $105^{\circ} \mathrm{C}$. Weighing was done until constant weight was achieved. Determination of soil conductivity was done in soil suspension with the aid of digital conductivity meter (Ikon, India).

The structural characteristics of the soil samples were determined at the Microbiology laboratory of Covenant University, Ota, Ogun State. Texture classification of the raw soil was then carried out and its physicochemical characteristics were determined as follows: $24.6 \%$ sand; $45.7 \%$ silt; $26.8 \%$ clay; neutral $\mathrm{pH}$ i.e. 7.2 ; total nitrogen content of $15.62 \mathrm{mg} / \mathrm{kg}$ and total phosphorus of $3.15 \mathrm{mg} / \mathrm{kg}$.

\subsection{Analysis of total petroleum hydrocarbon (TPH) composition}

The determination of the soil TPH was done according to the method of Das and Mukherjee (2007). In doing this, extraction was carried out on $10 \mathrm{~g}$ soil using $100 \mathrm{ml}$ of hexane, methylene chloride $\left(\mathrm{CH}_{2} \mathrm{Cl}_{2}\right)$, and chloroform. Pooling of the three extracts was done and drying was carried in a fume cabinet by solvent evaporation under a gentle nitrogen stream over $\mathrm{Na}_{2} \mathrm{SO}_{4}$ at room temperature. Concentration was then carried out with a rotary evaporator until a final volume of $3.0 \mathrm{ml}$ was achieved. After this, the amount of residual TPH was determined by measuring the final weight of the sample which was $30,300 \mathrm{mg} / \mathrm{kg}$.

\subsection{Assessment of bacterial populations}

Evaluation of the heterotrophic bacteria was done by pour plate method (Ayandiran et al., 2014; Ayandiran and Dahunsi, 2017). In doing this, each collected soil sample was diluted with sterile distilled water and a dilution of $10^{7}$ was subsequently plated onto nutrient agar and plate count agar. The inoculated plates were incubated at $35{ }^{\circ} \mathrm{C}$ and between 24 and $48 \mathrm{~h}$ after which examination of bacteria growth was done. Total population of the hydrocarbon utilizing bacteria (HUB) was obtained by pour plate method on Minimal Salts Medium (MSM) using the crude petroleum as the sole source of carbon. The composition of the medium in $\mathrm{g} / \mathrm{l}$ of distilled water is $\mathrm{NaCl} 10.0 ; \mathrm{KCl}, 0.29 ; \mathrm{MgSO}_{4} .7 \mathrm{H}_{2} \mathrm{O}, 0.42 ; \mathrm{KH}_{2} \mathrm{PO}_{2}, 0.83 ; \mathrm{NaNO}_{3}$, $0.42 ; \mathrm{Na}_{2} \mathrm{HPO}_{4}, 1.25$. Twenty (20) g of Agar agar powder was used to solidify the medium with a final pH of 7.27 before autoclaving. Crude petroleum was used at $1 \%(\mathrm{v} / \mathrm{v})$ as sole source of carbon for metabolism.

\subsection{Isolation of crude petroleum utilizing bacteria}

Isolation of crude petroleum utilizing bacteria species was obtained by enrichment of the samples in the crude petroleum mixed with the minimal salt medium. One gram of soil sample was poured into a $200 \mathrm{ml}$ conical flask already containing 50 $\mathrm{ml}$ of the media according to the method of Roy et al. (2014). The MSM was supplemented with $1 \%$ (v/v) crude oil as the sole source of carbon and energy. Incubation was done by shaking on rotatory shaker incubator at 180 rpm at room temperature for 14 days. After incubation, $1 \mathrm{ml}$ of the enrichment culture was taken and serially diluted to $10^{4}$ and plated using spread plate method on the mineral salt agar (MSA) in duplicates. Crude petroleum was supplied by soaking filter paper' in crude petroleum and placed on the cover of the inoculated plated and incubated for seven days at $35{ }^{\circ} \mathrm{C}$. The taxonomic scheme of Bergey's manual of determinative Bacteriology (Holt, 1994) was employed in the identification of selected bacteria with emphasis on the morphology and biochemical characteristics. 


\subsection{Hydrocarbon biodegradation}

The isolated bacteria strains were monitored in $200 \mathrm{ml}$ flasks already containing $50 \mathrm{ml}$ MSM amended with $1 \%(\mathrm{v} / \mathrm{v})$ of sterile crude petroleum as the only substrate. Washing of the strains was carried out in peptone water for $15 \mathrm{~h}$ before inoculation and the experiment was carried out in duplicates. Flasks containing only crude petroleum without bacterial inoculants were used as control.

\subsection{Utilization of petroleum products}

Kerosene and engine oil were also used to amend MSM media and the flasks were all placed on the rotatory shaker at $180 \mathrm{rpm}$ for 21 days. Reduction in values of $\mathrm{pH}$, increase in total bacterial count, and increase in optical density and reduction in residual oil concentration which indicated bacterial degradation were all monitored and recorded. Growth was also monitored at $72 \mathrm{~h}$ interval and recorded. Bacterial strains that could grow on the crude petroleum with the liquid and solid media were noted and were identified using the basic microbiological techniques.

\subsection{Gas Chromatographic (GC) analysis}

\subsubsection{Residual oil extraction process}

The process of extracting the residual oil in the flask from the above experiments was done by adding $20 \mathrm{ml}$ of hexane to resulting culture in a flask and shaking was done vigorously. Removal of the aqueous phase was achieved using a funnel to separate the oil from the medium and the residual oil concentrations were then measured using Gas Chromatography (GC). The same process of oil extraction was repeated for the broth in the control flask and the values obtained in the GC result was expressed as a percentage of the control result.

\subsubsection{Analysis of the oil extracts}

One $\mu \mathrm{l}$ of the resulting hexane extracts was obtained using the Hewlett Packard 6890 powered HP Chemo Station (Rev A 09.01 1206) software. The GC was equipped with a flame ionization detector (FID) and $30 \mathrm{~m}$ long HP-6 column (the diameter of the internal column is $0.25 \mathrm{~mm}$ and the thickness of the film is $0.25 \mu \mathrm{m}$ ). Nitrogen was used as the carrier gas and the temperatures of the injector and detectors were controlled to be at $250{ }^{\circ} \mathrm{C}$ and $350{ }^{\circ} \mathrm{C}$ respectively. The column was programmed at start up temperature of $100^{\circ} \mathrm{C}$ which was maintained for about $3 \mathrm{~min}$, then ramped at $10^{\circ} \mathrm{C}$ per min to 250 ${ }^{\circ} \mathrm{C}$ for another $5 \mathrm{~min}$.

\subsection{Investigation of presence of plasmid and its effects on hydrocarbon biodegradation}

\subsubsection{Extraction of the plasmids and gel electrophoresis}

The plasmid DNA was extracted from the isolated bacterial strains using the conventional method and the nucleic acid concentration and purity was checked using Thermo Scientific Nano Drop 2000 Spectrophotometer machine. The extracted plasmids were then loaded on the wells of $0.7 \%$ horizontal agarose gel electrophoresis tank. Electricity was supplied at $70 \mathrm{~V}$ for $3 \mathrm{~h}$ and ethidium bromide was used to mark the gel and the bands were viewed with an Ultraviolet transilluminator. The molecular sizes of the different plasmids were compared with RPI plasmid from E. coli strain JC 3272 using 1-Kbp weight as the marker.

\subsubsection{Plasmid curing}

Isolated bacterial strains were inoculated into lactose broth amended with the crude petroleum and incubated for 18 to $24 \mathrm{~h}$. After $18 \mathrm{~h}$ incubation, $1 \mu \mathrm{l}$ of the culture was added to $5 \mathrm{ml}$ of lactose broth containing $5 \mathrm{ml}$ of ethidium bromide as the curing agent and this was incubated at $37^{\circ} \mathrm{C}$ for $72 \mathrm{~h}$. After incubation, the culture was diluted and inoculated onto nutrient agar plates using pour plate method and incubated at $37^{\circ} \mathrm{C}$ for $24 \mathrm{~h}$. Colonies were counted and then sub-cultured onto Minimal Salt agar amended with crude petroleum and on nutrient agar. Plates were incubated overnight at $37^{\circ} \mathrm{C}$ for $72 \mathrm{~h}$. The colonies that grew on nutrient agar but not on MSM supplemented with crude petroleum were then isolated and considered as cured. The cured bacterial strains were then sub-cultured in minimal salt medium with the crude petroleum as the only carbon source to confirm their ability to utilize the crude petroleum.

\subsection{Statistical analysis}

Data were analyzed using Microsoft Excel 2010 tool pack. The mean values were used for the tables and the mean percentage of the values were used in plotting the graphs

\section{Results}

\subsection{Physicochemical properties of soil samples}

The physicochemical properties which include the $\mathrm{pH}$, temperature nitrate, phosphate, potassium, conductivity, moisture content and total organic contents and in the oil polluted soil samples are presented in Table 1. 
Table 1

Physicochemical properties of soil samples.

\begin{tabular}{llll}
\hline Parameters & Concentration & & \\
\cline { 2 - 4 } & Soil A & Soil B & Soil C \\
\hline Soil structure & Packed Silt Loam & Packed Silt Loam & Loose Sandy Loam \\
Moisture content $(\%)$ & 13.67 & 13.53 & 7.79 \\
$\mathrm{pH}$ & 6.83 & 6.64 & 6.62 \\
Temperature $\left({ }^{\circ} \mathrm{C}\right)$ & 29.80 & 29.40 & 29.40 \\
Conductivity $(\mu \mathrm{S} / \mathrm{cm})$ & 1.082 & 1.064 & 1.079 \\
Potassium $(\mathrm{mg} / \mathrm{kg})$ & 1.54 & 1.62 & 10.87 \\
Phosphate $(\mathrm{mg} / \mathrm{kg})$ & 1.65 & 1.87 & 1.95 \\
Total Organic Carbon $(\mathrm{TOC})(\%)$ & 14.0 & 15.5 & 24.1 \\
Nitrate $(\mathrm{mg} / \mathrm{kg})$ & 2.65 & 3.05 & 2.87 \\
\hline
\end{tabular}

Table 2

Identification of bacterial isolates.

\begin{tabular}{|c|c|c|c|c|}
\hline Biochemical reaction & Bacillus sp. (SB4) & Pseudomonas sp. (SC8) & Acinetobacter sp. (SC12) & Serratia sp. (SC11) \\
\hline Gram Reaction & +ve Rod & -ve Rod & -ve short Rods & -ve short Rods \\
\hline Mobility & Motile & Motile & Non motile & - ve \\
\hline Indole & - ve & - ve & - ve & + ve \\
\hline Methy Red & - ve & - ve & - ve & + ve \\
\hline Voges-Proskauer & + ve & - ve & + ve & + ve \\
\hline Citrate & + ve & + ve & - ve & - ve \\
\hline Urease & - ve & + ve & - ve & + ve \\
\hline Nitrate & $+\mathrm{ve}$ & + ve & - ve & + ve \\
\hline Triple Sugar Iron & * & * & $\mathrm{K} / \mathrm{K}$ & $\mathrm{A} / \mathrm{A}$ \\
\hline Catalase & $+\mathrm{ve}$ & + ve & + ve & + ve \\
\hline Oxidase & $+\mathrm{ve}$ & + ve & $+\mathrm{ve}$ & - ve \\
\hline Mannitol & $\mathrm{F}$ & $\mathrm{NF}$ & $\mathrm{NF}$ & + ve \\
\hline Maltose & $+\mathrm{ve}$ & $\mathrm{NF}$ & $\mathrm{NF}$ & $\mathrm{NF}$ \\
\hline Lactose & NF & $\mathrm{NF}$ & $\mathrm{NF}$ & $\mathrm{NF}$ \\
\hline Glucose & $\mathrm{NF}$ & - ve & + ve & F with gas \\
\hline Sucrose & - ve & + ve & - ve & + ve \\
\hline Starch Hydrolysis & $+\mathrm{ve}$ & - ve & ${ }^{*}$ & - ve \\
\hline Lysin & - ve & + ve & - ve & + ve \\
\hline Arginine & - ve & + ve & - ve & + ve \\
\hline Omithine & - ve & $+\mathrm{ve}$ & - ve & - ve \\
\hline
\end{tabular}

+ve-positive, -ve-negative, A-Acid, K-Alkali, F-Fermentative, NF-Non Fermentative, ${ }^{*}$-Not Determined.

\subsection{Enumeration of microbial populations}

The total heterotrophic bacteria count was within the range of $2.6 \times 10^{7}-4.5 \times 10^{7} \mathrm{cfu} / \mathrm{g}$ while the crude petroleum utilizing bacteria population ranges $1.2-1.5 \times 10^{4} \mathrm{cfu} / \mathrm{g}$. The percentage at which crude petroleum utilizing bacteria occurs relative to the total heterotrophic bacteria shows that the hydrocarbon utilizing bacteria within the heterotrophic populations were less than $0.5 \%$. This was indicative of the fact that only a small population of the bacteria community sampled was capable of utilizing hydrocarbons. Soil sample $C$ gave the highest percentage of degraders while the highest number of heterotrophic bacteria was seen in soil sample B.

\subsection{Taxonomic identification of crude oil degraders}

Soil samples enrichment with $1 \%(\mathrm{v} / \mathrm{v})$ crude oil resulted in the isolation of four bacteria strains. A bacteria isolated from Soil B (SB4) was identified as Bacillus sp. while the remaining three isolated from Soil C (SC8, SC11 and SC12) were identified as Pseudomonas, Serratia and Acinetobacter spp respectively. Only these four isolates were selected for further studies as representative pure strains. Table 2 shows the identification of the bacteria isolates.

\subsection{Growth of bacteria strains on crude oil}

Test for substrate specificity of hydrocarbon degradation was carried out by inoculating isolated bacteria into $250 \mathrm{ml}$ Erlenmeyer flasks; each containing $50 \mathrm{ml}$ MSM broth supplemented with $1 \%(\mathrm{v} / \mathrm{v})$ crude petroleum. Agitation was then carried out at $180 \mathrm{rpm}$ at $30^{\circ} \mathrm{C}$ for several days using a rotary shaker. Optical densities, total viable count and pH of inoculated flasks were measured and recorded at three days interval. The growth rates were recorded as shown in Fig. 1. All bacteria strains were able to grow on the medium. Bacillus sp. (SB4) exhibited best growth between the 12th and the 18th day. Total viable count increases from $1.0 \times 10^{7}(\mathrm{cfu} / \mathrm{ml})$ on day 3 to $5.5 \times 10^{9}(\mathrm{cfu} / \mathrm{ml})$ on day 18 before declining to $5.0 \times 10^{9}(\mathrm{cfu} / \mathrm{ml})$. There was a decrease in $\mathrm{pH}$ from 7.27 to 6.4. Pseudomonas sp. (SC8) showed increase in total viable count from $1.0 \times 10^{7}$ 


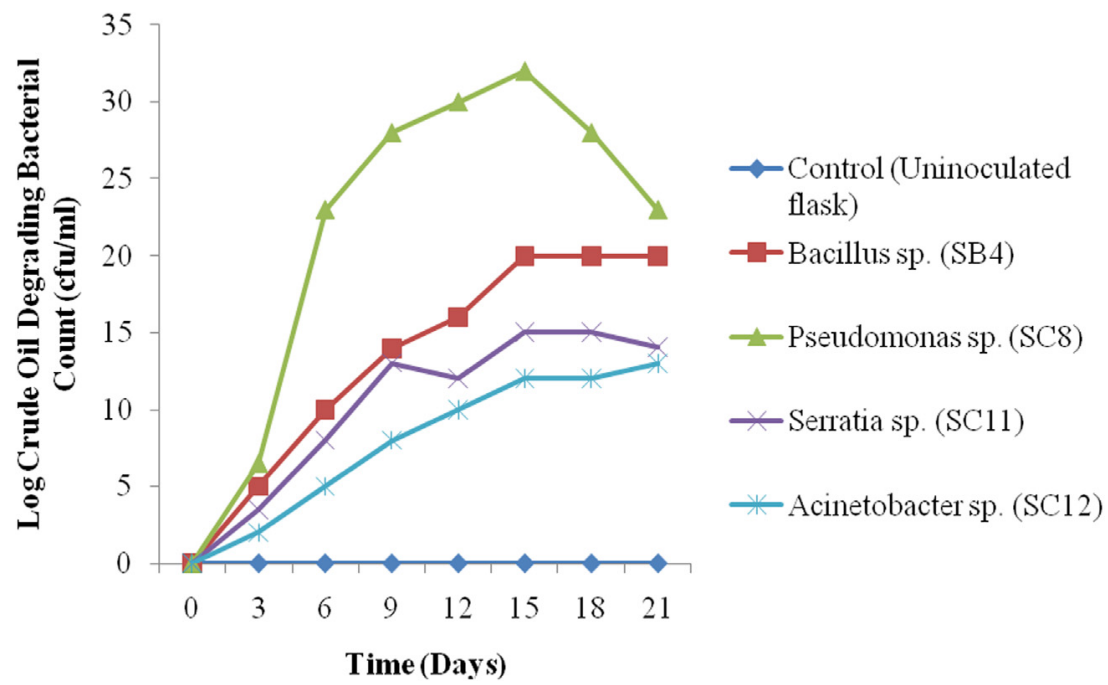

Fig. 1. Growth curve of Bacteria species on crude oil (1\% crude oil after 21 days of incubation). Values presented are averages of three replicate determinations.

Table 3

Growth of bacteria strains on different hydrocarbon substrates.

\begin{tabular}{lllll}
\hline Hydrocarbon & Bacillus $s p$. (SB4) & Pseudomonas sp. (SC8) & Serratia sp. (SC11) & Acinetobacter sp. (SC12) \\
\hline Crude oil & HG & HG & PG & PG \\
Kerosene & GG & HG & PG & PG \\
Engine oil & GG & HG & NG & PG \\
\hline
\end{tabular}

HG-Heavy growth ( $\left.>10 \times 10^{4} \mathrm{Cfu} \mathrm{g}^{-1}\right)$, GG-Good growth (Between $5 \times 10^{4} \mathrm{Cfu} \mathrm{g}^{-1}$ and $\left.10 \times 10^{4} \mathrm{Cfu} \mathrm{g}^{-1}\right)$, PG-Poor growth $\left(<2 \times 10^{4} \mathrm{Cfu} \mathrm{g}^{-1}\right)$, NG-no growth, all substrates were supplied at $1 \%(\mathrm{v} / \mathrm{v})$ and cultures were incubated for 21 days.

$(\mathrm{cfu} / \mathrm{ml})$ on day 3 to $7.5 \times 10^{9}(\mathrm{cfu} / \mathrm{ml}) \mathrm{pH}$ also decreases from 7.27 to 6.02 . The optical density increases considerably from 0 on day 1 to 1.41 on day 21. For the Serratia sp., increase in growth was slow ranging from $1.0 \times 10^{9}$ (cfu/ml) to $4.5 \times 10^{9}$ (cfu/ml) on days 15 to 18 with a decrease in the $\mathrm{pH}$ from 7.27 to 6.4. Acinetobacter $\mathrm{sp}$. also showed an increase in the total viable count and optical density with a decrease in $\mathrm{pH}$.

\subsection{Substrate specificity of hydrocarbon degraders}

Tests were carried out to determine the capability of the bacteria strains to grow on different hydrocarbon substrates. In this, MSM supplemented with the selected $1 \%(\mathrm{v} / \mathrm{v})$ hydrocarbon substrate as the sole source of carbon and energy was used. Incubation was carried out at room temperature on a rotatory shaker at $180 \mathrm{rpm}$ for 21days. The process of depletion was monitored by increase in turbidity, increase in the cell mass and reduction in residual oil level. This was compared with the uninoculated control. The hydrocarbons tested are crude oil, kerosene and engine oil. The result showing the growth of the bacterial strains on different hydrocarbon substrate used is presented in Table 3.

\subsection{Gas Chromatographic (GC) analysis}

Gas Chromatographic analysis of TPH detected the presence of C9-C30 carbons. The PAHs detected includes Naphthalene, Acenaphthene, Acenaphthylene, Anthracene, Benzo(a)pyrene, Benzo(a)anthracene, Chrysene, Fluoranthene, Fluorene, Phenanthrene, Benzo(b)fluoranthene, Benzo(k)fluoranthene, Pyrene, Indeno(1,2,3-cd)pyrene, Dibenzo(a,h)anthracene and Benzo(g,h,i)perylene.

\subsection{TPH and PAH depletion analysis}

The TPH and PAH value for all growth culture on day 1 was 9798.93 and $59.12 \mathrm{ppm}$ respectively (Fig. 2). On the day 21, the inoculated culture containing different bacteria strains have reduced the TPH content to an average of $7165.12 \mathrm{ppm}$ while PAH also to an average of $39.92 \mathrm{ppm}$ respectively. Fig. 2 represents percentage depletion profile of the total petroleum hydrocarbon (TPH) and polycyclic aromatic hydrocarbon (PAH) profile for each identified bacteria strains with $1 \%$ (v/v) crude oil after 21 days of incubation. In this study, the amount of aliphatic hydrocarbon depleted by Bacillus sp. (SB4) was 36\% while the aromatic hydrocarbon was $42 \%$. Pseudomonas sp. (SC8) was able to deplete $43 \%$ aliphatic hydrocarbon and $49 \%$ aromatic 


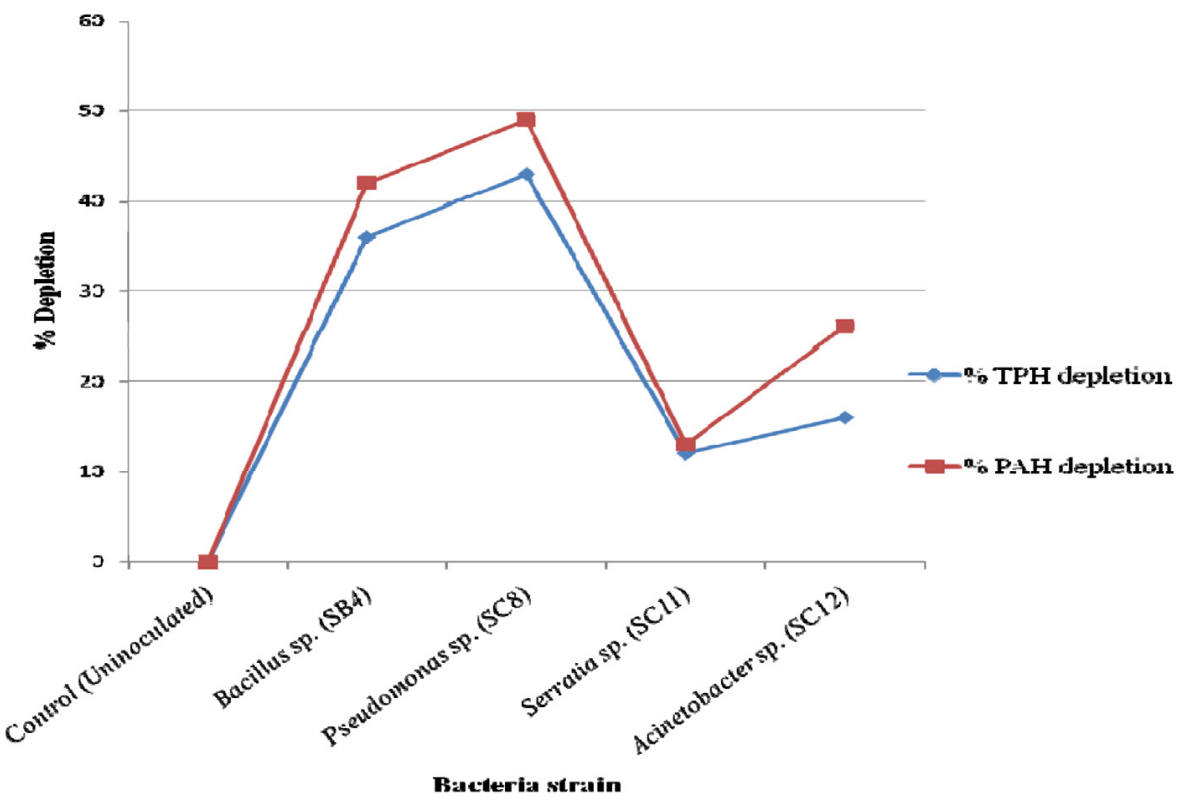

Fig. 2. Percentage depletion of total petroleum hydrocarbon (TPH) and polycyclic aromatic hydrocarbon (PAH) profile for each identified bacteria strains with $1 \%$ crude oil after 21 days of incubation. Values presented are averages of three replicate determinations. Key: Control (uninoculated flask), SB4-MSM inoculated with Bacillus sp., SC8-MSM inoculated with Pseudomonas sp., SC11-MSM inoculated with Serratia sp., SC12-MSM inoculated with Acinetobacter $s p$.

hydrocarbons. Hence, the highest depletion rate for this study. Serratia sp. (SC11) has the lowest depletion rate of aliphatic hydrocarbon $12 \%$ and $13 \%$ for the aromatic hydrocarbon. For the Acinetobacter sp. (SC12), the percentage depletion was 26\% for the aliphatic hydrocarbon and $16 \%$ for the aromatic hydrocarbon as shown in the figure.

\subsection{Determination of percentage degradation of the aliphatic and aromatic components of crude petroleum}

The results showed in Fig. 3a confirmed the capability of the bacteria strains to grow and metabolize the aliphatic components of the crude petroleum. The bacteria strains could grow on the hydrocarbon component because of their ability to use the carbon content as a source of energy. The oil component depletion did not follow a regular pattern because nearly all components of the hydrocarbon were depleted at the varying rates.

In this study, nearly all component of crude petroleum ranging from C9 to C30 were reduced by actions of bacteria strains with over $50 \%$ degradation of the aliphatic component of the crude petroleum. Bacillus $s p$. (SB4) had a percentage degradation of between $24 \%$ and $57 \%$ for the aliphatic component of the crude petroleum. Highest percentage (38 to $67 \%$ ) of degradation of the aromatic was achieved by Pseudomonas sp. While the Serratia and Acinetobacter spp. had 12 to $29 \%$ and 20 to $40 \%$ degradation respectively. All the bacterial strains could not degrade nonadecane C19. Pseudomonas sp. (SC8) reduced all the components of C9 to C30 with the exception of the C19 and the same trend was observed for Bacillus sp. (SB4). However, Serratia sp. (SC11) could not degrade C12 and C19 while Acinetobacter sp. (SC12) was also found to reduce all the C9 to C30 with the exception of $\mathrm{C} 19$ as shown in the figure.

Fig. 3b shows the polycyclic aromatic components of the crude petroleum and their rate of degradation. Bacillus sp. (SB4) was able to reduce all the aromatic components of the petroleum; Benzo(b) flouranthene was best degraded (68\%) while the Flourene and Anthracene (20\% each) were least degraded. Pseudomonas sp. (SC8) was also able to reduce all the aromatic components of the petroleum; Benzo(b)flouranthene was also best degraded (73\%) while Acenaphthylene (30\%) was least degraded. Serratia sp. (SC11) was not able to degrade Benzo(a)Anthracene (0\%), Chrysene (0\%), Benzo(a)pyrene (0\%) while Pyrene was degraded by $29 \%$. Acinetobacter $s p$. was able to reduce all the components of the petroleum used; Dibenzo(a,h)Anthracene (54\%) was best degraded by this strain and the least degraded was Acenaphthylene (12\%).

\subsection{GC fingerprints of the residual oil}

As shown in 4(a-e), all the flasks inoculated with the isolated bacteria strains showed some reduction and in some cases disappearance of the main alkane peaks compared to the GC fingerprints of residual oil from the uninoculated control flask. 


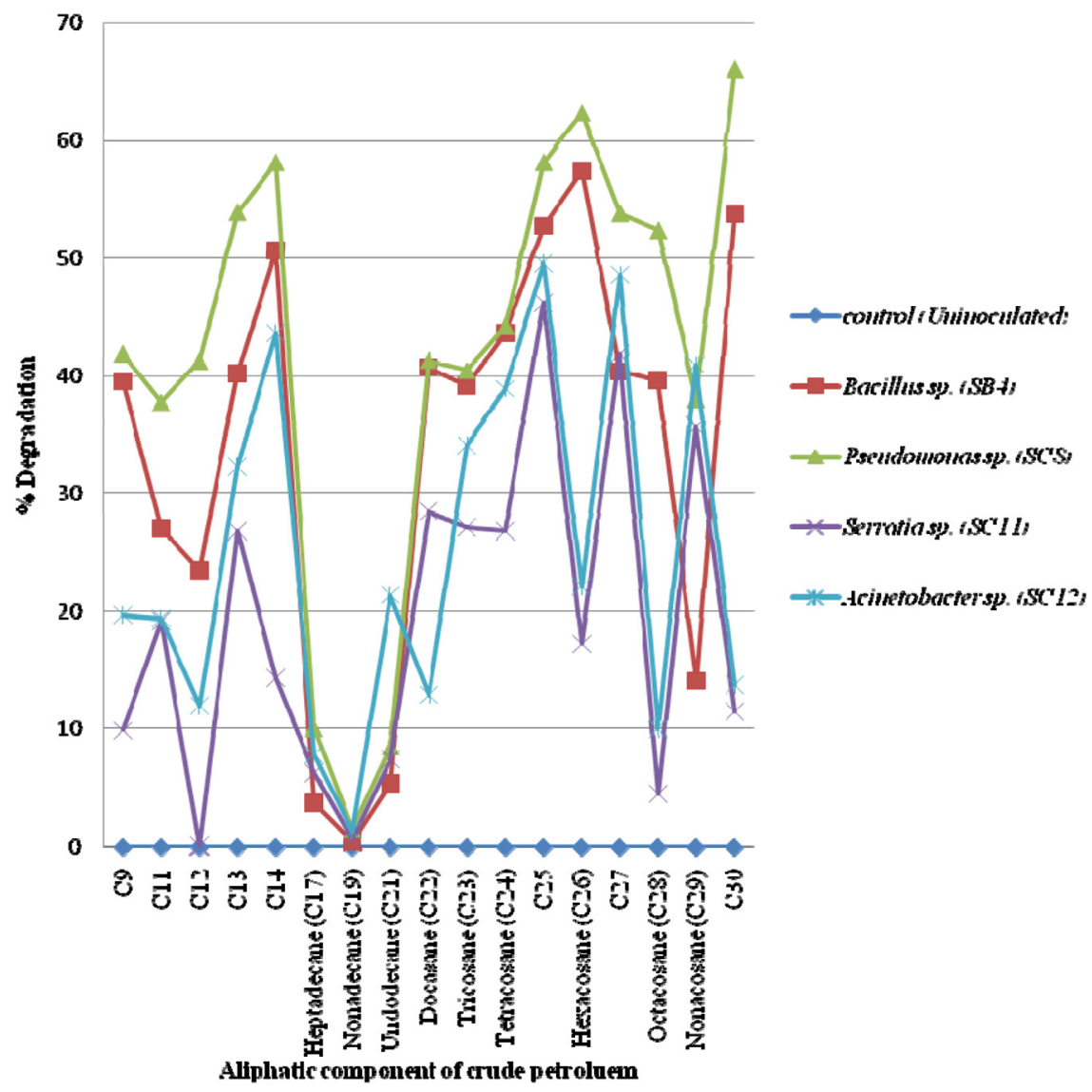

Fig. 3a. Polycyclic aliphatic hydrocarbon (PAH) \% degradation profile for each identified bacteria strains with $1 \%$ crude oil after 21 days of incubation. Percentage degradation represents net decrease (in FID area counts) in experimental cultures, compared with that of the uninoculated control. Values presented are averages of three replicate determinations. Key: Control (uninoculated flask), SB4-MSM inoculated with Bacillus sp., SC8-MSM inoculated with Pseudomonas sp., SC11-MSM inoculated with Serratia sp., SC12-MSM inoculated with Acinetobacter sp.

\subsection{Plasmid Analysis}

It was discovered that all the strains that were successfully cured by serial sub-culturing in nutrient broth (i.e., all except Bacillus sp.) lost their hydrocarbon-degrading ability. Fig. 5 shows the agarose gel electrophoretic separation profiles of plasmids from cured and uncured strains of the four bacteria used in the study. As seen, they also lost their hydrocarbon biodegradation ability, indicating that the capacity to degrade hydrocarbons is plasmid related in all the strains studied except the Bacillus sp. Also, cured Pseudomonas sp. also lost the ability to degrade crude oil, kerosene and unspent lubricating oil. In Serratia, Pseudomonas and Acinetobacter spp., some deletions occurred. Despite several subcultures, no cured Bacillus strain was obtained, although in the wild strain, one plasmid was seen in agarose gel. This shows that another strain of Pseudomonas $s p$. which does not produce green pigmentation and does not possess two plasmids was discovered during this study. This strain Pseudomonas sp. has a high degradative capacity and could be compared with the others in future studies.

\section{Discussion}

The microorganisms (bacteria and fungi) which are part of the ecosystem are responsible for the biodegradation of the hydrocarbons. Biodegradation of crude oil often occur as a result of the attack of microorganisms on both the aliphatic and the aromatic components of crude oil and other hydrocarbons (Yuan et al., 2000). The ratio of hydrocarbon utilizing bacteria relative to the heterotrophic bacteria was below $0.5 \%$ (Table 1 ) suggesting that the environment where the samples were collected were only recently exposed to petroleum pollutants. From recent studies, it was seen that uncontaminated soils normally have ratios of hydrocarbon utilizing bacteria relative to the heterotrophic bacteria less than $1 \%$ (Atlas, 1995). Therefore, pollution by petroleum could have made the normal heterotrophic bacteria to become hydrocarbon utilizing bacteria, due to the fact that polluted sites have unbalanced nutrient cycles. Since the means of survival is very competitive, a new metabolic pathways have been adopted which helps the bacteria to adapt to the adverse conditions. 


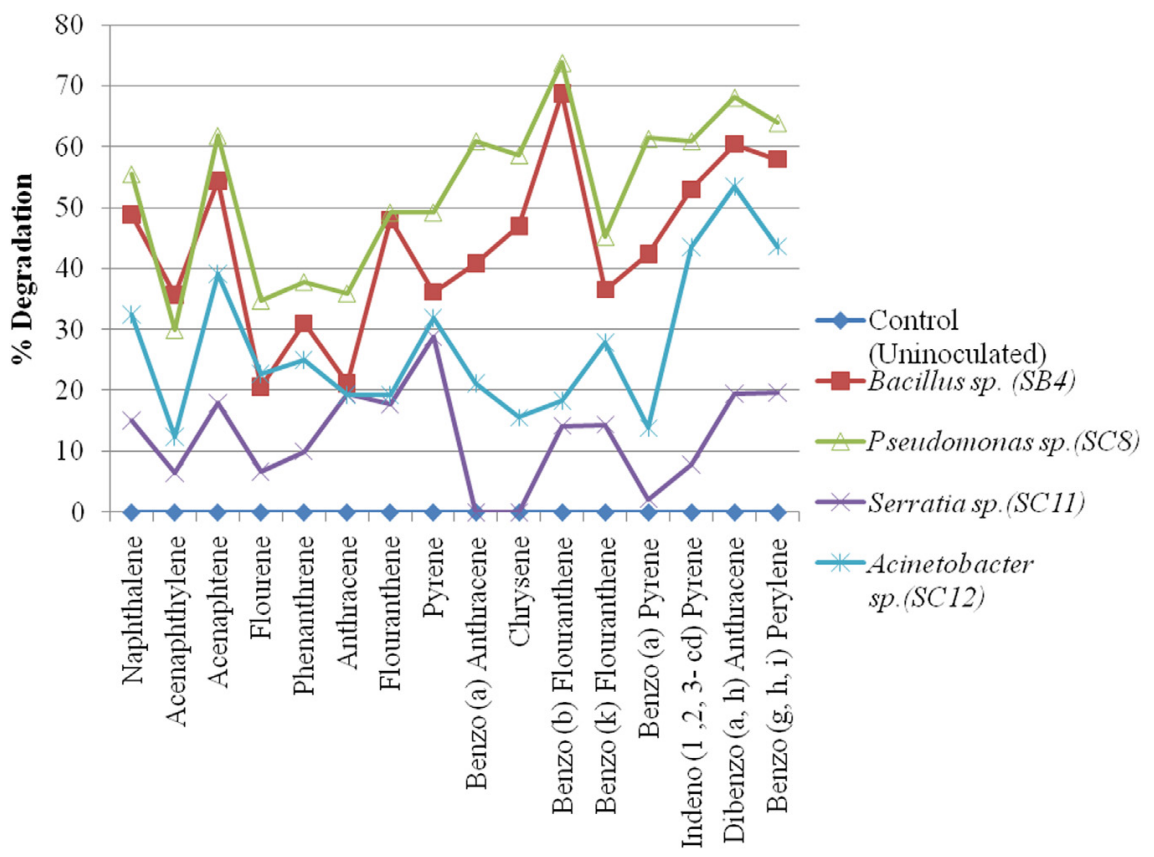

PAH component of crude petroleum

Fig. 3b. Polycyclic aromatic hydrocarbon (PAH) \% degradation profile for each identified bacteria strains with $1 \%$ crude oil after 21 days of incubation. Percentage degradation represents net decrease (in FID area counts) in experimental cultures, compared with that of the uninoculated control. Values presented are averages of three replicate determinations. Key: Control (uninoculated flask), SB4-MSM inoculated with Bacillus sp., SC8-MSM inoculated with Pseudomonas sp., SC11-MSM inoculated with Serratia sp., SC12-MSM inoculated with Acinetobacter sp.

Four bacterial strains isolated during this study were able to utilize the crude petroleum and other hydrocarbon although at different rates. The substrates were metabolized resulting in the production of organic acids and reduction in the pH levels as also found by Nwankwegu and Onwosi (2017). The result obtained during the substrate specificity and growth studies are similar to the findings of Zhang et al. (2010) who found that the two organisms (Bacillus and Pseudomonas spp.) can degrade crude oil under optimum growth conditions. The crude oil utilizing bacteria identified under this study have also been isolated and observed by a previous research (Ijah and Antai, 2003). The high capability of Bacillus sp. isolated from the soil in degrading crude oil has been repeatedly observed in both contaminated and uncontaminated soils (Mohamad et al., 2004; Ismail et al., 2014).

The percentage of biodegradation of crude petroleum by the bacterial strains in this study was high and achieved by Bacillus sp. (SB4) which degraded Benzo(b)flouranthene by 68\% and Pseudomonas sp. (SC8) which degraded same component by $73 \%$ using $1 \%(\mathrm{v} / \mathrm{v})$ crude oil. Analysis of the crude petroleum after biodegradation showed that the aliphatic components are more easily degraded than aromatic components. These results are in agreement with those obtained previously by Adebusoye et al. (2007).

It is shown that nearly all of the aliphatic hydrocarbons were significantly metabolized within 21 days of incubation with near disappearance of residual oil in the entire experimental flasks. The aliphatic component C19 resisted degradation while the other linear alkanes were degraded at relatively different rates regardless of the number of $C$ atoms of the linear hydrocarbon. This is similar to the earlier reports by Chen et al. (2015) and Thenmozhi et al. (2011). It is therefore not surprising that both bacteria strains were able to grow on all aromatics tested with the exception of anthrancene, chrysene and Benzo(a)pyrene which could not be used by Serratia sp. as sole sources of carbon and energy.

Oxygenase are known to be complex enzymes with high ability to catalyze a wide variety of reactions (Taketani et al., 2010). Also, plasmid degradative enzyme system have been reported as capable of mineralizing other PAHs such as phenanthrene and anthracene (Nkwelang et al., 2008). The results of this study revealed that bacteria strains were able to grow effectively on crude oil, metabolizing both the aliphatic and aromatic components because bacteria can grow rapidly on hydrocarbons at elevated concentrations. The degrading capabilities in the bacterial strains may be attributed to presence of many enzymes which include the oxygenases, and the presence of many metabolic activities and genes for functional pathways. Although as reviewed by Mona et al. (2016), the presence of both alkane and aromatic hydrocarbon-degrading genes in bacterial strains appear to be common and plasmid encoded. Even though degradative genes can be located on either chromosome or plasmid, it has been reported that processes which encode degradation routes of different aromatic and aliphatic hydrocarbons are normally located on plasmids (Chikere et al., 2011). These authors extracted plasmids from Pseudomonas and Acinetobacter spp. isolated from oil-contaminated soils which conferred the ability to degrade naphthalene. 


\section{(CONTROL)}

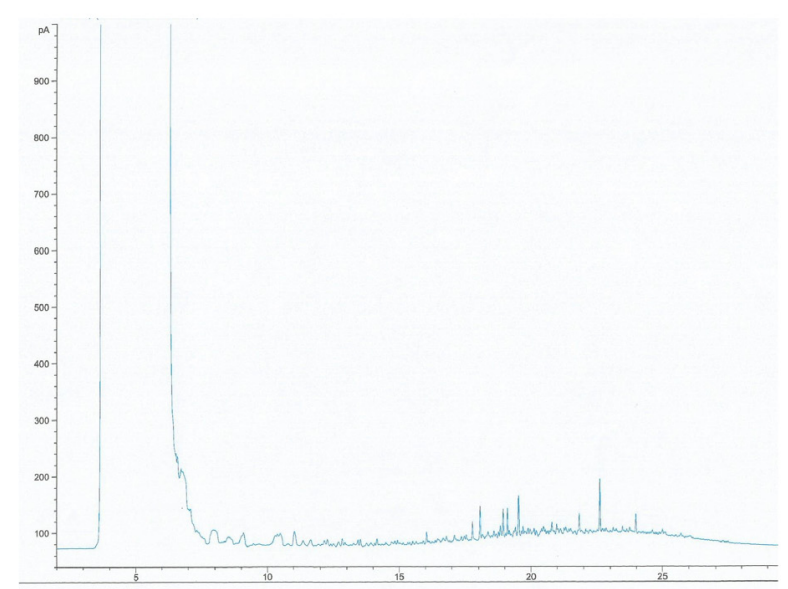

(SB4)

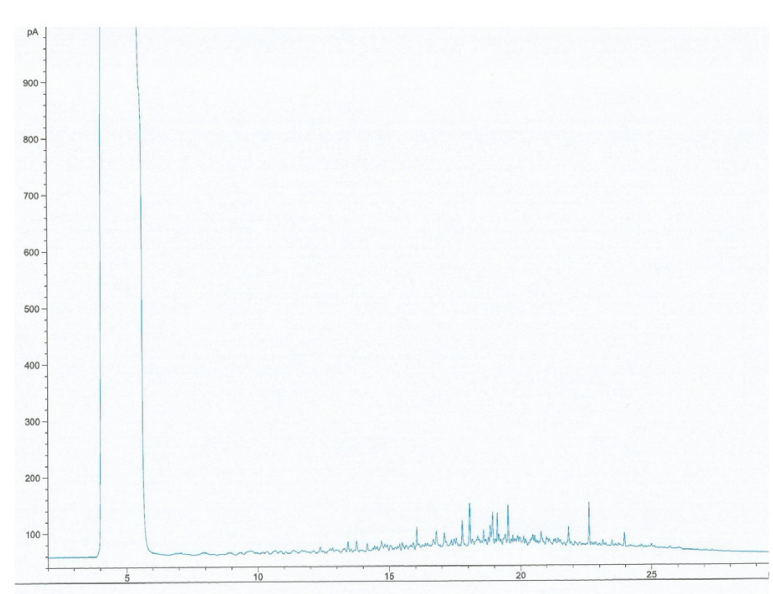

(SC8)

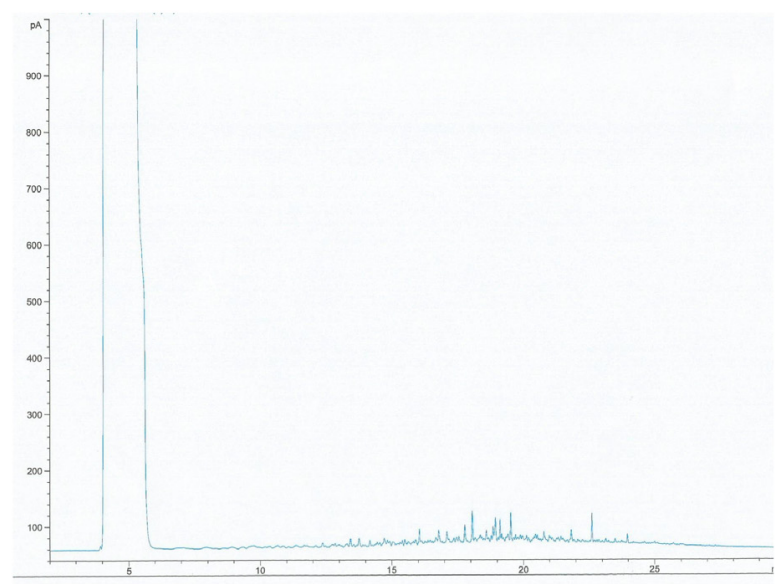

(a)

Fig. 4. (a-e): Gas Chromatographic fingerprints for residual oil recovered after 21 days of degradation of Bonny light crude oil. Key: Control-Uninoculated, SB4-Bacillus sp., SC8-Pseudomonas sp., SC11-Serratia sp., SC12-Acinetobacter sp. after 21 days of incubation. The crude oil was supplied at a concentration of $1 \%(\mathrm{v} / \mathrm{v})$. 
(SC11)

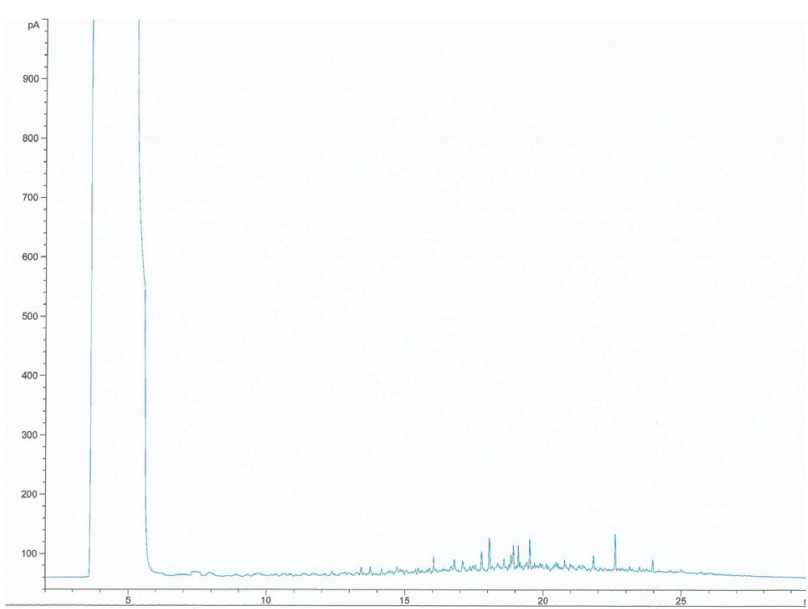

(SC12)

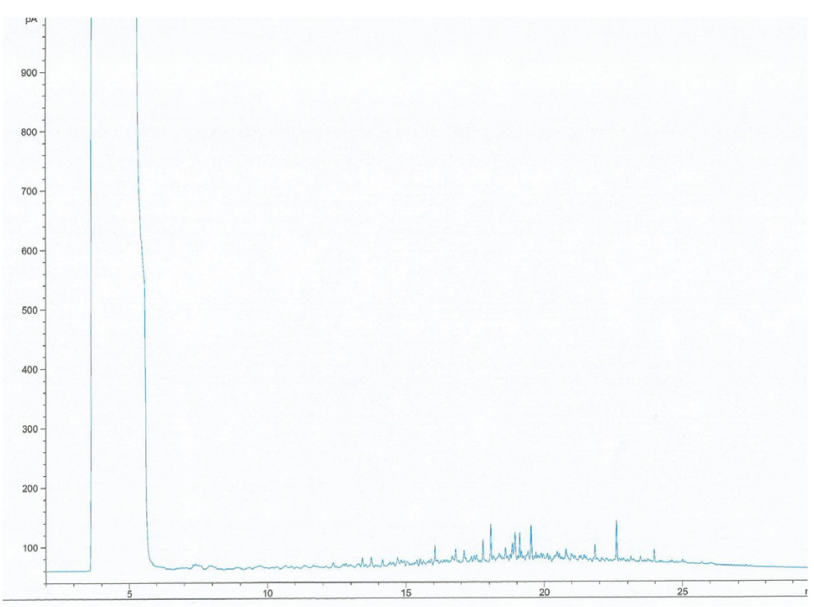

(b)

Fig. 4. (continued).

The study also demonstrated the presence and also the role of two plasmids in Pseudomonas sp. catabolic pathways for alkane and naphthalene which was not obtained in this study.

\section{Conclusion}

As seen in this study, bioremediation has the potential to effectively and economically restore contaminated environments. Also, the understanding of the diversity of microbial community's in petroleum contaminated environment has been shown to play an essential role in getting a better insight into potential oil degraders and to understand their genetics and biochemistry. As reported in this study, the degradative genes can be isolated and recombined into an artificial Escherichia coli to make a genetically modified microorganism which could be used for bioremediation process.

\section{Acknowledgment}

Authors wishes to appreciate our laboratory staff for their immense contributions to this research.

\section{Conflicts of interest}

Authors declare no conflict of interest whatsoever. 


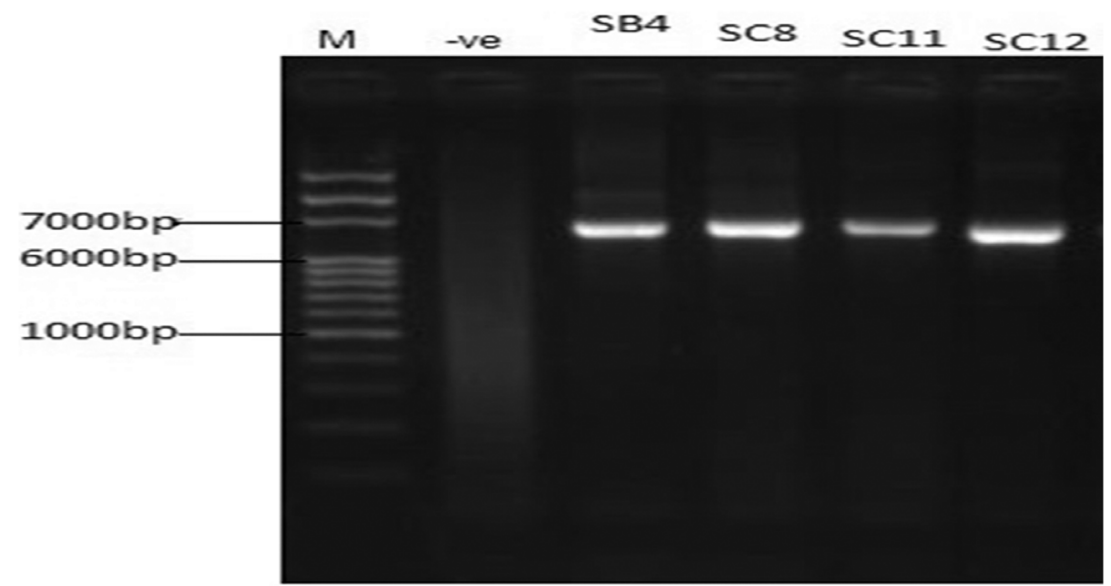

Fig. 5. Electrophoretic Separation profiles of plasmids from cured and non-cured bacterial isolates. Lane 1 plasmid represents DNA ladder of $1 \mathrm{kbp}$ size. Lane $2,4,7$ and 9 show the plasmid profiles from the non-cured isolates while lane $3,5,6$, and 8 show the plasmid profiles from the cured isolates respectively.

\section{References}

Adebusoye, S.A., Ilori, M.O., Amund, O.O., Teniola, O.D., Olatope, S.O., 2007. Microbial degradation of petroleum hydrocarbons in a polluted tropical stream. World J. Microbiol. Biotechnol. 23, 149-159.

Adekunle, A.A., Adeniyi, A.O., 2015. Biodegradation of petroleum oil by Fungi isolated from Treculia Africana (Dec'ne) seeds in Nigeria. Afr. J. Environ. Sci. Technol. 9 (3), 126-135.

APHA, 2012. Standard Methods for Examination of Water and Waste-Water, twenty second. American Public Health Association, Washington DC.

Atlas, R.M., 1995. Bioremediation of petroleum pollutants. Int. Biodeterior. Biodegradat. 32, 317-327.

Ayandiran, T.A., Ayandele, A.A., Dahunsi, S.O., Ajala, O.O., 2014. Microbial assessment and prevalence of antibiotic resistance in polluted Oluwa River, Nigeria. Egypt. J. Aquat. Res. 40, 291-299.

Ayandiran, T.A., Dahunsi, S.O., 2017. Microbial evaluation and occurrence of antidrug multi-resistant organisms among the indigenous Clarias species in River Oluwa, Nigeria. J. King Saud Univ.-Sci. 29, 96-105.

van Beilen, J.B., Funhoff, E.G., 2007. Alkane hydroxylases involved in microbial alkane degradation. Appl. Microbiol. Biotechnol. 741, $13-21$.

van Beilen, J.B., Funhoff, E.G., van Loon, A., Just, A., Kaysser, L., Bouza, M., Holtackers, R., Röthlisberger, M., Li, Z., Witholt, B., 2006. Cytochrome P450 Alkane hydroxylases of the CYP153 family are common in alkane-degrading eubacteria lacking integral membrane alkane hydroxylases. Appl. Environ. Microbiol. 72 (1), 59-65.

Callaghan, A.V., Morris, B.L., Pereira, I.C., McInerney, M.J., Austin, R.N., Groves, J.T., Kukor, J.J., Suflita, J.M., Young, L.Y., Zylstra, G.J., Wawrik, B., 2012. The genome sequence of Desulfatibacillum alkenivorans AK-01: a blueprint for anaerobic alkane oxidation. J. Environ. Microbiol. 14, 101-113.

Chen, M., Xua, P., Zenga, G., Yang, C., Huang, D., 2015. Bioremediation of soils contaminated with polycyclic aromatic hydrocarbons, petroleum, pesticides, chlorophenols and heavy metals by composting: Applications, microbes and future research needs. Biotechnol. Adv. J. 33, 745-755.

Chikere, C.B., Okpokwasili, G.C., Chikere, B.O., 2011. Bacterial diversity in a tropical crude oil-polluted soil undergoing bioremediation. Afr. J. Biotechnol. 8 (11), 2535-2540.

Dahunsi, S.O., Owamah, H.I., Ayandiran, T.A., Oranusi, S.U., 2014. Drinking water quality and public health of selected towns in South Western Nigeria. Water Qual. Exp. Health 6, 143-153.

Das, K., Mukherjee, A.K., 2007. Crude petroleum-oil biodegradation efficiency of Bacillus subtilis and Pseudomonas aeruginosa strains isolated from a petroleum-oil contaminated soil from North-East India. Bioresour. Technol. 98, 1339-1345.

Groudev, S., Georgiev, P., Spasova, I., Nicolova, M., 2014. Decreasing the contamination and toxicity of a heavily contaminated soil by in situ bioremediation. J. Geochem. Explor. 144, 374-379.

Haritash, A.K., Kaushik, C.P., 2009. Biodegradation aspects of Polycyclic Aromatic Hydrocarbons (PAHs): A review. J. Hazard. Mater. 169, 1-15.

Hesnawi, R.M., Mogadami, F.S., 2013. Bioremediation of Libyan Crude Oil-Contaminated Soil under Mesophilic and Thermophilic Conditions. In: APCBEE Proc. Vol. 5. pp. 82-87.

Holt, J.G. (Ed.), 1994. Bergey's Manual of Systematic Bacteriology. Williams and Wilkins, Baltimore, p. 816.

Ijah, U.J., Antai, S.P., 2003. The potential use of Chicken-drop microorganisms for oil spill remediation. Environ. 23, 89-95.

Ismail, H.Y., Ijah, U.J.J., Riskuwa, M.L., Allamin, I.I., 2014. Biodegradation of spent engine oil by bacteria isolated from the rhizosphere of legumes grown in contaminated soil. Int. J. Environ. 3 (2), 63-75.

Jackson, M.L., 1973. Soil Chemical Analysis. Prentice Hall of India Ltd, New Delhi, p. 23.

Janbandhu, A., Fulekar, M.H., 2011. Biodegradation of phenanthrene using adapted microbial consortium isolated from petrochemical contaminated environment. J. Hazard. Mater. 187, 333-340.

Mohamad, F., Raja, A.R., Basri, M., 2004. Biodegradation of hydrocarbons in soil by consortium. Int. Biodeterior. Biodegradat. 54, 61-67.

Mona, S.Z., Nabila, E.B., Samy, I.S., Refat, A.Y., 2016. Bioremediation of organic xenobiotics (Review). World Rural Obs. 8 (1), 1-2.

Nie, Y., Tang, Y.Q., Li, Y., Chi, C.Q., Cai, M., Wu, X.L., 2012. The genome sequence of Polymorphum gilvum SL003B-26A1 (T) reveals its genetic basis for crude oil degradation and adaptation to the saline soil. PLoS ONE 7, 31261.

Nishant, J., Neepa, P., Nirali, R., Nikhil, B., Rajnicant, R., 2016. Production of LiP by Phanerochaete chrysosporium MTCC 787 through solid state fermentation of wheat strain and assessing its activity against reactive Black B. Int. J. Adv. Res. 4 (1), 812-819.

Nkwelang, G., Henri, F., George, E.N., Antai, S.P., 2008. Studies on the diversity, abundance and succession of hydrocarbon utilizing microorganisms in tropical soil polluted with oily sludge. Afr. J. Biotechnol. 7 (8), 1075-1080.

Nwankwegu, A.S., Onwosi, C.O., 2017. Bioremediation of gasoline contaminated agricultural soil by bioaugmentation Author links open overlay panel. Environ. Technol. Innov. 7, 1-11. 
Nwinyi, O.C., Olawore, O.A., 2017. Biostimulation of spent engine oil contaminated soil using Ananas comosus and Solanum tuberosum peels. Environ. Technol. Innov. 8, 373-388.

Roy, A.S., Baruah, R., Borah, M., Singh, A.K., Boruah, H.P.D., Saikia, N., Deka, M., Dutta, N., Bora, T.C., 2014. Bioremediation potential of native hydrocarbon degrading bacterial strains in crude oil contaminated soil under microcosm study. Int. Biodeterior. Biodegradat. 94, 79-89.

Silva, I.S., Grossman, M., Durrant, L.R., 2009b. Degradation of polycyclic aromatic hydrocarbons (2-7 rings) under microaerobic and very-low-oxygen conditions by soil fungi. Int. Biodeterior. Biodegradat. 63 (2), 224-229.

Silva, I.S., da Costa dos Santos, E., de Menezes, C.R., de Faria, A.F., Franciscon, E., Grossman, M., Durrant, L.R., 2009a. Bioremediation of a polyaromatic hydrocarbon contaminated soil by native soil microbiota and bioaugmentation with isolated microbial consortia. Bioresour. Technol. 100, 4669-4675.

Suja, F., Rahim, F., Taha, M.R., Hambali, N., Razali, M.R., Khalid, M., Hamzah, A., 2014. Effects of local microbial bioaugmentation and biostimulation on the bioremediation of total petroleum hydrocarbons (TPH) in crude oil contaminated soil based on laboratory and field observations. Int. Biodeterior. Biodegradat. 90, 115-122.

Taketani, R.G., Franco, N.O., Rosado, A.S., van Elsas, J.D., 2010. Microbial community response to a simulated hydrocarbon spill in mangrove sediments. World J. Microbiol. 48, 7-15.

Thenmozhi, R., Nagasathya, A., Thajuddin, N., 2011. Studies on biodegradation of used engine oil by consortium cultures. Adv. Environ. Biol. 5, $1051-1057$.

Ting, W.T.E., Yuan, S.Y., Wu, S.D., Chang, B.V., 2011. Biodegradation of phenanthrene and pyrene by Ganoderma lucidum. Int. Biodeterior. Biodegradat. 65, 238-242.

Wu, Y.R., Luo, Z.H., Vrijmoed, L.L., 2010. Biodegradation of anthracene and benz[a]anthracene by two Fusarium solani strains isolated from mangrove sediments. Bioresour. Technol. 101 (96), 66-72.

Xu, Y., Lu, M., 2010. Bioremediation of crude oil-contaminated soil: Comparison of different biostimulation and bioaugmentation treatments. J. Hazard. Mater. 183, 395-401.

Yenn, R., Borah, M., Boruah, H.P.D., Roy, A.S., Baruah, R., Saikia, N., Sahu, O.P., Tamuli, A.K., 2014. Phytoremediation of abandoned crude oil contaminated drill sites of Assam with the aid of a hydrocarbon-degrading bacterial formulation. Int. J. Phytorem. 16, 909-925.

Yuan, S.Y., Wei, S.H., Chang, B.V., 2000. Biodegradation of polycyclic aromatic hydrocarbons by a mixed culture. Chemosphere 41 (9), $1463-1468$.

Zhang, Z., Gai, L., Hou, Z., Yang, C., Ma, C., Wang, Z., Sun, B., He, X., Tang, H., Xu, P., 2010. Characterization and biotechnological potential of petroleumdegrading bacteria isolated from oil-contaminated soils. Bioresour. Technol. 101, 8452-8456. 